\title{
BIBLIOGRAPHY OF INTERNATIONAL LAW CONCERNING ASIAN AFFAIRS*
}

\section{Editorial introduction}

Except for a few minor modifications this bibliography follows our usual format: it provides information on books, articles and other materials dealing with Asian topics and, in exceptional cases, it includes other publications considered of interest. Only English language publications are cited.

In the preparation of this bibliography good use has been made of book review sections in established professional journals of international law, Asian studies and international affairs. Special mention should be made of the bibliography on Public International Law published by the Max Planck Institute for Comparative Public Law and International Law at Heidelberg, Germany, and of the regular list of acquisitions of the Peace Palace Library in The Hague, The Netherlands.

The headings used in this year's bibliography are:

1. General

2. States and groups of states

3. Territory and jurisdiction

4. Sea, rivers and water-resources

5. Air and Space

6. Environment

7. International conflict and disputes.

8. War, peace and neutrality, armed conflict and peace-keeping

9. International criminal law

10. Peaceful settlement of international disputes

11. Diplomatic and consular relations

12. Individuals, groups of persons - human rights

13. Decolonization and self-determination

14. International economic relations

15. Development

16. Information and communication

17. United Nations and other international/regional organizations

* Edited by J.J.G. Syatauw, General Editor. 


\section{GENERAL}

Bellows, Michael D. (ed.), Asia in the 21st Century: Evolving Strategic Priorities, Washington D.C., National Defense University Press, 1994, 265 pp.

BRESNAN, JoHn, From Dominoes to Dynamos: the Transformation of Southeast Asia, New York, Council on Foreign Relations Press, 1994, 115 pp.

Judicial Decisions in Japan, 36 JAIL 182-227 (1993).

Ko SwaN SiK, The Indonesian Law of Treaties 1945-1990, Dordrecht, Nijhoff, 1994, 227 pp.

KUX, DENNIS, Estranged Democracies: India and the United States 1941-1991, Washington DC, National Defense University Press, 1994, 514 pp.

LERNER, TSURIEL, The Practice and Case Law of Israel in Matters Related to International Law, 27 Israel Law Review 668-700 (1993).

Mandelbaum, Michael (ed.), Central Asia and the World: Kazakhstan, Uzbekistan, Tajikistan, Kyrgyzstan and Turkmenistan, New York, Council on Foreign Relations Press, 1994, 251 pp.

SATO, KoJI, The Pursuit of the Principle of International Cooperation in the Constitution of Japan, 36 JAIL 5-16 (1993).

UNESCO, International Law: News and Information from Asia and the Pacific, Bangkok, Unesco Regional Unit for Social and Human Sciences - Principal Regional Office of Asia and the Pacific, 1988, 29 pp. Also: 2 International Law, no. 1, June 1988.

WeStBROOK, DAVID A., Islamic International Law and Public International Law: Separate Expressions of World Order, 33 Virginia Journal of International Law 819-897 (1993).

ZimmermanN, NURIT, The Practice and Case Law of Israel in Matters Related to International Law, 28 Israel Law Review 179-205 (1994).

\section{STATES AND GROUPS OF STATES}

Aruri, NASEer H. and Carroll, JoHn J., A New Palestinian Charter, 23 Journal of Palestine Studies 5-17 (1994).

GazIT, Shlomo, The Declaration of Principles between Israel and the PLO: the Security Issues, 47 Studia Diplomatica 41-53 (1994).

Madhusoodhanan, V., Law of Foreign State Immunity: Changing Patterns of International Law and Indian State Practice, 35 Journal of the Indian Law Institute 95-107 (1993).

Tervala, Victor K., Ferdinand Marcos and the Act of State Doctrine: an Analysis of Republic of the Philippines v. Marcos, 13 Maryland Journal of the International Law of Trade 7-144 (1988) [case note concerning the decision of the US Court of Appeals, 806 F.2d 344 (2d Cir. 1986)].

Whelan, DeIRDRE E., The Commercial Activity Exception in the Foreign Sovereign Immunities Act: Saudi Arabia v. Nelson, 27 Creighton Law Review 1069-1104 (1994).

\section{TERRITORY AND JURISDICTION}

Blake, Gerald H. (ed.), World Boundaries Series, Vol. 1: Global Boundaries, Clive H. SCHOFIELD (ed.), London, Routledge, 1994, 125 pp. 
BlaKe, Gerald H. (ed.), World Boundary Series, Vol. 2: The Middle East and North Africa, Clive H. SCHOFIELD (ed.), London, Routledge, 1994, 204 pp.

Blake, Gerald H. (ed.), World Boundary Series, Vol. 3: Eurasia, CARL GrundY-WARR (ed.), London, Routledge, 1994, $219 \mathrm{pp}$.

BlaKe, Gerald H. (ed.), World Boundary Series, Vol. 4: The Americas, PasCal O. GiROT (ed.), London, Routledge, 1994, 202 pp.

Blake, Gerald H. (ed.), World Boundary Series, Vol. 5: Maritime Boundaries, Gerald H. BLAKE (ed.), London, Routledge, 1994, 177 pp.

BROWN, HARRY, The Iraq-Kuwait Boundary Dispute: Historical Background and the UN Decisions of 1992 and 1993, 2 Boundary \& Security Bulletin 66-80 (1994).

BULLOCH, JOHN (ed.), GCC Border Disputes Seminar: with Special Reference to Iraq and Kuwait, GCSS Staff Report, London, Gulf Centre for Strategic Studies, 1992, 89 pp.

DJIWANDONO, J. SoEdJATI, Intra-ASEAN Territorial Disputes: the Sabah Claim, 22 IQ 34-43 (1994).

FINNIE, DavID H., Shifting Lines in the Sand: Kuwait's Elusive Frontier with Iraq, Cambridge Mass., Harvard Univ. Press, 1992, 221 pp.

KLABBERS, JAN, No More Shifting Lines?, The Report of the Iraq-Kuwait Boundary Demarcation Commission, 43 International and Comparative Law Quarterly $904-913$ (1994).

LAMB, AlASTAIR, Kashmir: a Disputed Legacy, 1846-1990, Hertingfordbury, Roxford Books, 1991, $368 \mathrm{pp}$.

LUSTICK, IAN S., Unsettled States, Disputed Lands: Britain and Ireland, France and Algeria, Israel and the West Bank/Gaza, Ithaca, New York, Cornell University Press, 1993, 576 pp.

MCLACHLAN, KeITH (ed.), The Boundaries of Modern Iran, London, UCL Press, 1994, 150 pp.

MIYOSHI, MASAHIRO, Considerations of Equity in the Settlement of Territorial Boundary Disputes [2 International Law in Japanese Perspective], Dordrecht, Nijhoff, 1993, 246 pp.

MORRIS, BENNY, Israel's Border Wars, 1949-1956: Arab Infiltration, Israeli Retaliation and the Countdown to the Suez War, Oxford, Clarendon Press, 1993, 451 pp.

NESTER, WILLIAM, Japan, Russia and the Northern Territories: Continuities, Changes, Obstacles, Opportunities, 14 Third World Quarterly 717-734 (1993).

PRICE, Glen W., Legal Analysis of the Kurile Island Dispute, 7 Temple International and Comparative Law Journal 395-422 (1993).

SCHOFIELD, RICHARD N., Kuwait and Iraq: Historical Claims and Territorial Disputes, 2nd ed. (rev. and enl.), London, Royal Institute of International Affairs, 1993, 207 pp.

SCHOFIELD, RICHARD N., Kuwait and Iraq: Historical Claims and Territorial Disputes, 2. ed., London, Royal Institute of International Affairs, 1993, 207 pp.

SCHOFIELD, RICHARD N. (ed.), Territorial Foundations of the Gulf States, London, UCL Press, 1993, $256 \mathrm{pp}$.

SCHOFIELD, RICHARD (ed.), South-West Arabia, 6 vols., [Farnham Common] Archive Editions (Arabian Geopolitics), 1993 [vol. 1: Boundaries, Territorial Claims and Disputes (I), 757 pp.; vol. 2: Boundaries, Territorial Claims and Disputes (II), 566 pp.; vol. 3: The Shaping of State Territory 
in South-West Arabia (I), 758 pp.; vol. 4: The Shaping of State Territory in South-West Arabia (II), 363 pp. and 767 pp.; vol. 5: The Shaping of State Territory in South-West Arabia (III), 703 pp.; vol. 6: Western Involvement in South-West Arabia], 721 pp.

SCHOFIELD, RICHARD (ed.), The Iraq-Kuwait Dispute, 7 vols., [Farnham Common] Archive Editions, 1994, [vol. 1: Evolution of the Iraq-Kuwait International Boundary on Land and Sea, part I: 1830-1994, 751 pp.; vol. 2: Evolution of the Iraq-Kuwait International Boundary on Land and Sea, part II: 1936-1957, 730 pp.; vol. 3: Evolution of the Iraq-Kuwait International Boundary on Land and Sea, part III: 1949-1957, 731 pp.; vol. 4: Evolution of the Iraq-Kuwait International Boundary on Land and Sea, part IV: 1958-1993, 825 pp.; vol. 5: The International Status of Kuwait, part I, 1888-1913, 845 pp.; vol. 6: The International Status of Kuwait, part II, 1914-1994, 856 pp.; vol. 7: Maps - Cassette with 18 separate maps, 18 pp.

SHEHADEH, RAJA, Questions of Jurisdiction: a Legal Analysis of the Gaza-Jericho Agreement, 23 Journal of Palestine Studies 8-25 (1994).

\section{SEA, RIVERS AND WATER-RESOURCES}

Agreements concerning Cross-Strait Activities (done at Singapore, April 29, 1993), 32 ILM 12171227 (1993).

AKAHA, TSUNEO, Bilateral Fisheries Relations in the Seas of Japan and Okhotsk: a Catalyst for Cooperation or Seed of Conflict?, 11 Ocean Yearbook 384-408 (1994).

Ali, ALmeEN, Land-locked States and International Law: with Special Reference to the Role of Nepal, New Delhi, South Asian Publ., 1989, 238 pp.

ANDERSON III, H.E., Applicable Arbitration Rules for Maritime Disputes in Australia and Hong Kong, 6 University of San Francisco Maritime Law Journal 387-421 (1994).

Ashley RoACh, J; Oliver, John T. and SMith, Robert W., Iran's Maritime Claims, United States Bureau of Oceans and International Environmental and Scientific Affairs, Washington D.C., Office of Ocean Affairs, 1994, 32 pp.

BELLER, RICHARD D., Analyzing the Relationship between International Law and International Politics in China and Vietnam's Territorial Dispute over the Spratly Islands, 29 Texas International Law Journal 293-320 (1994).

BENVENISTI, EYAL and GVIRTZMAN, HAIM, Harnessing International Law to Determine IsraeliPalestinian Water Rights: the Mountain Aquifer, 33 Natural Resources Journal 543-567 (1993).

BERgin, ANTHONY and HAWARD, MARCUS, The Last Jewel in a Disintegrating Crown the Case of Japanese Distant Water Tuna Fisheries, 25 ODIL 187-215 (1994).

BUlloch, JOHN and ADEL DARWISH, Water Wars: Coming Conflicts in the Middle East, London, Golancz, 1993, 224 pp.

CAPONERA, DANTE A., Legal Aspects of Transboundary River Basins in the Middle East: the Al Asi (Orontes), the Jordan and the Nile, 33 Natural Resources Journal 629-663 (1993).

CoQuia, Jorge R. and Feliciano, MYrna S., A Philippine Bibliography on the Law of the Sea, 12 Philippine Yearbook of International Law 179-194 (1986).

CorDnER, LeE G., The Spratly Islands Dispute and the Law of the Sea, 25 ODIL 61-74 (1994). 
CRAWford, JAmes and Rothwell, Donald R. (eds.), The Law of the Sea in the Asian Pacific Region: Developments and Prospects, Dordrecht, Nijhoff/Kluwer Academic Publishers, 1994, 284 pp.

DiChTER, HAROLD, The Legal Status of Israel's Water Policies in the Occupied Territories, 35 Harvard International Law Journal 565-594 (1994).

DZUREK, DANIEL J., Southeast Asian Offshore Disputes, 11 Ocean Yearbook, 157-178 (1994).

ENGLEFIELD, Managing Boundaries in the South China Sea, 2 Boundary and Security Bulletin 3638 (1994).

GAO, ZHIGUO, The South China Sea: from Conflict to Cooperation?, 25 ODIL 345-359 (1994).

GEORGE, MARY, The Spratly Islands: Maritime Delimitation, Malayan Law Journal cxlii-clx (31 December 1993).

Hindley, MichaEl and BRIDGE, JAMES, South China Sea: the Spratly and Paracel Islands Dispute, 50 The World Today 109-112 (1994).

HoNG, SeOung-Young and Jung-Keuk Kang, Current State and Long-term Strategy for the Korean Deep Seabed Mining Venture, in: International Advisory Conference on Deep Seabed Mining Policy, 5-6 September 1994, Seoul, Korea Ocean Research and Development Institute, 1994, 24 pp.

KIM, HYUN-SoO, The 1992 Chinese Territorial Sea Law in the Light of the UN Convention, 43 International and Comparative Law Quarterly 894-904 (1994).

KOREA OCEAN RESEARCH AND DEVELOPMENT INSTITUTE, Proceedings International Advisory Conference Deep Seabed Mining Policy, held at the Sheraton Walker-Hill Hotel, Seoul, Korea, September 5-6, 1994.

KWIATKOWSKA, BARBARA, Judge Shigeru Oda's Opinions in Law of the Sea Cases: Equitable Maritime Boundary Delimitation, 36 German Yearbook of International Law 225-294 (1993).

LOWI, MIRIAM R., Water and Power: the Politics of a Scarce Resource in the Jordan River, Cambridge, Cambridge University Press, 1993, 291 pp.

LOWI, MIRIAM, The Politics of Water under Conditions of Scarcity and Conflict: the Jordan River and Riparian States, Ann Arbor, UMI, 1990, 411 pp.

MATICS, KATHLEEN I. and MCDORMAN, TED L. (eds.), SEAPOL Workshop on Regime-Building In South-East Asia (1989: Phuket, Thailand, May 1-3, 1989) and SEAPOL Workshop on The Entry into Force of the Law of the Sea Convention: Issues and Prospects (Chiangmai, Thailand, May 2729, 1991), Selected Papers, Bangkok, South-East Asian Programme in Ocean Law, Policy and Management (SEAPOL), 1992, 180 pp.

MATICS, KATHLEEN I. and MCDORMAN, TED L. (eds.), SEAPOL, Overview Workshop on the Gulf of Thailand, 1993 (Kuala Lumpur, Malaysia, 20-22 July 1993), Summary and Selected Papers, Bangkok, South-East Asian Programme in Ocean Law, Policy and Management (SEAPOL), 1994, $81 \mathrm{pp}$.

Matics, Kathleen I. and MCDoRman, Ted L., SEAPOL: South-East Asian Programme in Ocean Law, Policy and Management: Selected Papers in Commemoration of the Entry into Force of the UN Convention of the Law of the Sea, Bangkok, 1994, 218 pp. 
Morgan, Joseph and Valencia, Mark J. (eds.), Atlas for Marine Policy in the East Asian Seas, East-West Center, Honolulu, Hawaii/Berkeley, California, University of California Press, 1992, $152 \mathrm{pp}$.

NEFF, DONALD, Israel-Syria: Conflict at the Jordan River 1949-1967, 23 Journal of Palestine Studies 26-40 (1994).

PARK, CHOON-HO, River and Maritime Boundary Problems between North Korea and China in the Tumen River and the Sea of Japan, 5 The Korean Journal of Defense Analysis 65-98 (1993).

RAU, ROBERT L., Maritime Security Developments in East and Southeast Asia: Association of Southeast Asian Nations, China and Japan Major Participants, 11 Ocean Yearbook $426-442$ (1994).

San Pablo-Baviera, Aileen (ed.), The South China Sea Disputes: Philippine Perspectives, Quezon City, Philippine-China Development Resource Center/Philippine Association for Chinese Studies, 1992, $58 \mathrm{pp}$.

SCHOFIElD, C., An Arms Race in the South China Sea?, 2 Boundary and Security Bulletin 39-48 (1994).

ShARMA, OM PRAKASH, Enforcement Jurisdiction in the Exclusive Economic Zone: the Indian Experience, 24 ODIL 155-178 (1993).

SINGH, T.R.P., Perspective on Deep Seabed Mining, in: International Advisory Conference on Deep Seabed Mining Policy (September 5-6, 1994, Seoul), Korea Ocean Research and Development Institute, 1994, 31 pp.

South-East Asian Programme in Ocean Law, Policy and Management, The UN Convention on the Law of the Sea in Southeast Asia: Problems of Implementation, SEAPOL Studies no. 3, Bangkok, $1991,139 \mathrm{pp}$.

South-East Asian Programme in Ocean Law, Policy and Management, Proceedings of the SEAPOL International Conference on the Implementation of the Law of the Sea Convention in the 1990's: Marine Environmental Protection and Other Issues (Denpasar, Indonesia 28-30 May 1990), published by Center for Archipelago Law and Development Studies, Bandung, 1992, 662 pp.

STEPAN, S., Portugal's Action in the International Court of Justice against Australia concerning the Timor Gap Treaty, 18 Melbourne University Law Review 918-927 (1992).

Stormont, William G., Managing Potential Conflicts in the South China Sea, 18 Marine Policy 353-356 (1994).

TANG, ZHENGYU, Marine Jurisdiction of the People's Republic of China: Legal Framework, Recent Developments, and Future Prospects, 25 Journal of Maritime Law and Commerce 251-278 (1994).

TsuruSAKI, KATSUYA, Current Deep Ocean Mining Technology Research in Japan, in: International Advisory Conference on Deep Seabed Mining Policy (5-6 September 1994, Seoul), Korea Ocean Research and Development Institute, 1994, 28 pp.

VALENCIA, MARK J. and DYKE, JON M. VAN, Vietnam's National Interests and the Law of the Sea, 25 ODIL 217-250 (1994).

VAlero, Gerardo M.C., Spratly Archipelago Dispute: Is the Question of Sovereignty still Relevant?, 18 Marine Policy 314-344 (1994).

Wang, Liyu and Pearse, Peter H., The New Legal Regime for China's Territorial Sea, 25 ODIL 431-442 (1994). 
WOLF, AARON, Water for Peace in the Jordan River Watershed, 33 Natural Resources Journal 797-839 (1993).

WOLF, AARON TORAB, The Impact of Scarce Water Resources on the Arab-Israeli Conflict: an Interdisciplinary Study of Water Conflict Analysis and Proposals for Conflict Resolution, Ann Arbor, UMI, 1992, 402 pp.

YATES, John and RoONWAL, GanPat S., Marine Science and Technology in India: Current Status, 18 Marine Policy 59-68 (1994).

ZoU, KeYUAN, China's Antarctic Policy and the Antarctic Treaty System, 24 ODIL 237-255 (1993).

\section{AIR AND SPACE}

[no entries]

\section{ENVIRONMENT}

Allen, Ted, The Philippine Children's Case: Recognizing Legal Standing for Future Generations, 6 Georgetown International Environmental Law Review 713-741 (1994).

BRANDON, CARTER \& RAMESH RAMANKUTTY, Toward an Environmental Strategy for Asia: a Summary of a World Bank Discussion Paper, Washington, DC, World Bank, 1993, 34 pp.

BROOKFIELD, HAROLD and BYRON, YVONNE (eds.), Southeast Asia's Environmental Future: the Search for Sustainability, Tokyo, United Nations University Press, 1993, 422 pp.

FORREST, RICHARD A., Japanese Aid and the Environment, 21 The Ecologist 24-32 (1991).

JASANOFF, SHEILA (ed.), Learning from Disaster: Risk Management after Bhopal, Philadelphia, Univiversity of Pennsylvania Press, 1994, 291 pp.

MUTTAGI, P.K., Controlling Pollution in Bombay and Calcutta, 18 Marine Policy 209-216 (1994).

O'CONNOR, DAVID, Managing the Environment with Rapid Industrialisation: Lessons from the East Asian Experience, Paris, Development Centre of the OECD, 1994, 218 pp.

PATHAK R.S., International Trade and Environmental Development: a View from India, 1 Indian Journal of Global Legal Studies 325-341 (1994).

PIASECKI, BRUCE W., Corporate Environmental Strategy: the Avalanche of Change since Bhopal, New York, Wiley, 1995, $180 \mathrm{pp}$.

PRODIPTO GOSH and AKSHAY JAITLY (eds.), The Road from Rio: Environment and Development Policy Issues in Asia, New Delhi, Tata Energy Research Institute, 1993, 218 pp.

REGE, VINOD, GATT-Law and Environment-related Issues Affecting the Trade of Developing Countries, 20 Journal of World Trade 95-169 (1994).

SANDler, Deborah (ed.), Protecting the Gulf of Aqaba: a Regional Environmental Challenge, Washington D.C., Environmental Law Institute, 1993, 512 pp. 
SHEARER, C. RUSSEll H., International Environmental Law and Development in Developing Nations: Agenda Setting, Articulation and Institutional Participation, 7 Tulane Environmental Law Journal 391-430 (1994).

\section{INTERNATIONAL CONFLICTS AND DISPUTES}

Gills, BARRY K., Prospects for Peace and Stability in Northeast Asia: the Korean Conflict, London, Research Institute for the Study of Conflict and Terrorism, 1995, $27 \mathrm{pp}$.

HINGORANI, AMAN, US Sanctions on the Indo-Russian Rocket-Engine Deal: a Subversion of the Missile Technology Control Regime, 28 Journal of World Trade 59-76 (1994).

VANDER Clute, NoRman, The Middle East: a Legal Update. Legal Aspects of the Arab Boycott, New York, Practising Law Institute, 1978, 528 pp.

\section{WAR, PEACE AND NEUTRALITY; ARMED CONFLICT AND PEACE-KEEPING}

Afghan Peace Accord, Islamabad, 7 March 1993, 46 Pakistan Horizon, 115-121 (1993).

BAKER, STUART G., Comparing the 1993 US Airstrike on Iraq to the 1986 Bombing of Libya: the New Interpretation of Article 51, 24 Georgia Journal of International and Comparative Law 99-116 (1994).

BALORO, JOHN, Aspects of the Law on the Responsibility of a Host State for Injuries to Foreign Investment during Internal Armed Conflict: The ICSID Award in Asian Agricultural Products Limited (AAPL) v. Republic of Sri Lanka, 18 South African Yearbook of International Law 105$126(1992 / 93)$.

BARBER, PETER, Scuds, Shelters and Retreating Soldiers: the Laws of Aerial Bombardment in the Gulf War, 31 Alberta Law Review 662-691 (1993).

BEN-MEIR, Alon, Israeli and Syrian "battle" for Equitable Peace, 33 International Problems 6-24 (1994).

BENNETT, ANDREW, LEPGOLD, JOSEPH and UNGER, DANNY, Burden-sharing in the Persian Gulf War, 48 IQ 39-75 (1994).

BENVENISTI, EYAL, The Israeli-Palestinian Declaration of Principles: a Framework for Future Settlement, 4 EJIL 542-554 (1993).

Bilateral Peace Negotiations Jordan-Israel Track Common Agenda (Initialled at Washington, 14 September 1993, 32 ILM 1522-1524 (1993).

BOBвITT, PHILIP, War Powers: an Essay on John Hart Ely's War and Responsibility: Constitutional Lessons of Vietnam and its Aftermath, 92 Michigan Law Review 1364-1400 (1994).

Chellaney, BRahma, Nuclear Proliferation: US-Indian Conflict, London, Sangam Books, 1993, $474 \mathrm{pp}$.

Clements, Kevin (ed.), Peace and Security in the Asia Pacific Region: Post-Cold War Problems and Prospects, Tokyo, United Nations University Press, 1993, 400 pp. 
Conduct of the Persian Gulf War, Final Report to Congress pursuant to Title V of the Persian Gulf Conflict Supplemental Authorization and Personnel Benefits Act of 1991 (Public Law 102-15), United States Department of Defense, Washington D.C., 1992, 824 pp.

COQUIA, JORGE R., Comparative Study of the RP-US Military Bases Agreement with Other US Military Agreements, 13 Philippine Yearbook of International Law 95-131 (1987).

Dalton, Jane GilliLand, The Influence of Law on Seapower in Desert Shield/Storm, 41 Naval Law Review 2 (1993).

DancheV, AleX \& Keohane, Dan (eds.), International Perspectives on the Gulf Conflict, 19901991, New York, Martin's Press, 1994, 332 pp.

De GutTRY, ANDrea and RonZitTI, NATAlino (eds.), Iran-Iraq War (1980-88) and the Law of Naval Warfare, Cambridge, Grotius Publications, 1993, 573 pp.

DemSa, Paul Meslam, International Peacekeeping Operations. Sinai, Congo, Cyprus, Lebanon and Chad: Lessons for the UN and OAU, Ann Arbor, UMI, 1989, 291 pp.

DINSTEIN, YORAM, The Israel Supreme Court and the Law of Belligerent Occupation: Deportations, 23 Israel Yearbook of Human Rights 1-26 (1993).

DOMB, FANIA, Judgements of the Supreme Court of Israel Relating to the Administered Territories, 23 Israel Yearbook of Human Rights 277-361 (1993).

DRIFTE, REINHARD, Japan's Rise to International Responsibilities: the Case of Arms Control, London, The Athlone Press, 1990, 112 pp.

Evans, Paul M., Managing Security Relations after the Cold War: Prospects for the Council for Security Cooperation in Asia Pacific, 22 IQ $62-69$ (1994).

FARHANG RAJAEE (ed.), The Iran-Iraq War: the Politics of Aggression, Gainesville, Univ. Press of Florida, 1993, 245 pp.

FREIER, SHALHEVETH, A Nuclear-weapon-free-zone in the Middle East and Effective Verification, 16 Disarmament 66-91 (1993).

FuKs-MANSFELD, R.G., War and Peace in Biblical and Post-biblical Judaism, 12/13 Grotiana (Assen, Netherlands) 5-12 (1991-92).

GHOSH, PARTA S., Nuclear Rivalry in South Asia: Strategic Imperatives and National Pride, London, Research Institute for the Study of Conflict and Terrorism, 1994, 22 pp.

Grammas, GeORGE N., Multilateral Responses to the Iraqi Invasion of Kuwait: Economic Sanctions and Emerging Proliferation Controls, 15 Maryland Journal of International Law and Trade 1-21 (1991).

HARRIS, SHELdon H., Factories of Death: Japanese Biological Warfare 1932-1945 and the American Cover-up, London/New York, Routledge, 1994, 297 pp.

INFELD, DANIElle L., Precision-guided Munitions Demonstrated their Pinpoint Accuracy in Desert Storm; But is a Country Obligated to Use Precision Technology to Minimize Collateral Civilian Injury and Damage? 26 The George Washington Journal of International Law and Economics 109-141 (1992).

ISMAEL, TARIQ Y. and ISMAEL, JAQUELINE S., The Gulf War and the New World Order: International Relations of the Middle East, Gainsville, University Press of Florida, 1994, 569 pp. 
KHADDURI, MAJID, Perspectives on the Gulf War, 15 Michigan Journal of International Law 847861 (1994).

KIM, MYONG-GI, The Korean War and International Law, Claremont, Paige Press, 1991, 291 pp.

KIM, GYE-DONG, Foreign Intervention in Korea, Aldershot, Dartmouth, 1992, 467 pp.

LeVIE, Howard S., The Korean Armistice Agreement and its Aftermath, 41 Naval Law Review 115-133 (1993).

MATTHEWS, KEN, The Gulf Conflict and International Relations, London, Routledge, 1993, 339 pp.

MCLeAn, ANDREw, Security, Arms Control and Conflict Reduction in East Asia and the Pacific: a Bibliography 1980-1991 (Bibliographies and Indexes in Law and Political Science; 19), London, Greenwood Press, 1993, 551 pp.

MOREL, BENOIT, Nuclear Non-Proliferation and the International Inspection Experience in Iraq, 16 Disarmament 103-121 (1993).

Munuera, Gabriel, Prospects for Security and Cooperation in the Mediterranean after PLOIsrael Agreement. A CSCM Revisited?, 5 Helsinki Monitor 48-59 (1994).

NAVIAS, MarTin, Proliferation in the Middle East and the North Asian Connection, 14 Arms Control 287-310 (1993).

NORMAND, ROGER and JOCHNICK, CHRIS, The Legitimation of Violence: a Critical Analysis of the Gulf War, 35 Harvard International Law Journal 387-416 (1994).

NYE JR., JOSEPH S. and SMITH, ROGER K., After the Storm: Lessons from the Gulf War, Lanham, MD, Madison Books, 1992, 415 pp.

OVEnDALE, RitchIE, The Origins of the Arab-Israeli Wars, 2nd ed., London, Longman, 1992, $308 \mathrm{pp}$.

PARKER, KAREN and CHEW, JENNIFER F., Compensation for Japan's World War II War-Rape Victims, 17 HICLR 497-549 (1994).

Pelcovits, Nathan A., The Long Armistice: UN Peacekeeping and the Arab-Israeli Conflict 1948-1960, Boulder, Westview Press, 1993, 264 pp.

QUIGLEY, JOHN, Missiles with a Message: the Legality of the United States Raid on Iraq's Intelligence Headquarters, 17 HICLR 241-274 (1994).

REISMAN, W. MiCHAEL, The Raid on Bagdad: Some Reflections on its Lawfulness and Implications, 5 EJIL 120-133 (1994).

Resolutions and Recommendations of the International Islamic Conference on the Current Situation in the Gulf, Makkah al-Moukarramah, Rabitat al-Alam al-Islami, 1411/1990, 27 pp.

ROWE, PETER (ed.), The Gulf War 1990-91 in International and English Law, London, Routledge/London, Sweet \& Maxwell, 1993, 463 pp.

SHALEV, ARYEH, Israel and Syria: Peace and Security on the Golan, Boulder, Westview Press, $1994,228 \mathrm{pp}$.

SIMON, DAN, The Demolition of Homes in the Israeli Occupied Territories, 19 Yale Journal of International Law 1-79 (1994). 
SMITH, ChrIs, India's ad hoc Arsenal: Direction of Drift in Defence Policy?, Oxford, Oxford University Press, 1994, 267 pp.

TERRY, JAMES P., Operation Desert Storm: Stark Contrasts in Compliance with the Rule of Law, 41 Naval Law Review 83-96 (1993).

Wengler, Wilhelm (ed.), Documents on the Arab-Israel Conflict: the Resolutions of the United Nations Organization 1978-1990, (Quellen zum internationalen Recht; 5c) Berlin, Berlin Verlag 1993, $551 \mathrm{pp}$.

YANAI, SHUNJI, Law concerning Cooperation for United Nations Peace-keeping Operations and Other Operations. The Japanese PKO Experience, 36 JAIL 33-75 (1993).

ZEDALIS, REX J., Gulf War Compensation Standard: Concerns under the Charter, 26 Revue Belge de Droit International 333-350 (1993).

\section{INTERNATIONAL CRIMINAL LAW}

LUKASHUK, IGOR I., The Nuremberg and Tokyo Trials: 50 Years Later, 20 Review of Central and East European Law 207-216 (1994).

\section{PEACEFUL SETTLEMENT OF INTERNATIONAL DISPUTES}

Al-SamaAn, YAHYA, The Settlement of Foreign Investment Disputes by Means of Domestic Arbitration in Saudi Arabia, 9 Arab Law Quarterly 217-237 (1994).

AldRICH, GeORge A., What Constitutes a Compensable Taking of Property? The Decisions of the Iran-United States Claims Tribunal, 88 American Journal of International Law 585-610 (1994).

AVANESSIAN, AIDA B., Iran-United States Claims Tribunal in Action, London, Graham \& Trotman/Martinus Nijhoff, 1993, 325 pp.

BEDJAOUI, MOHAMmed, The Arab World in ICC Arbitration, 3 The ICC International Court of Arbitration Bulletin 7-20 (1992).

BOND, STEPHEN R. and YAN, LAN, ICC Arbitration in the Asia/Pacific Region, 2 The ICC International Court of Arbitration Bulletin 5-48 (1991).

BOSMAN, LISE et al., The Iran-United States Claims Tribunal, 6 Hague Yearbook of International Law 239-284 (1993).

BRUNetTI, MAURIZIO, et al., The Iran-United States Claims Tribunal. A Joint Contribution, 5 Hague Yearbook of International Law 237-270 (1993).

International Court of Justice, Case concerning Maritime Delimitation and Territorial Questions between Qatar and Bahrain (Qatar v. Bahrain): Jurisdiction and Admissibility, Judgment of 15 February 1995, 76 pp.

Kaplan, N.; Spruce, J. and Moser, M.J., Hong Kong and China Arbitration: Cases and Materials, Hong Kong, Butterworths, 1994, 843 pp.

KaPlan, N., Hong Kong Arbitration: A Model for Arbitration: Hong Kong Four Years Experience in Arbitration under the Model Law, 1 Asia Law: the Journal for Asia Regional Counsel 23-27 (1995). 
LAPIDOTH, RUTH and HIRSCH, MOSHE (eds.), The Arab-Israel Conflict and its Resolution: Selected Documents, Dordrecht, Nijhoff, 1992, 387 pp.

LUBMAN, STANLEY B. and WAJNOWSKI, GREgORY C., International Commercial Dispute Resolution in China: a Practical Assessment, 4 American Review of International Arbitration 107178 (1993).

MOSER, MiCHAEL J., China's New International Arbitration Rules, 11 Journal of International Arbitration 5-24 (1994).

\section{DIPLOMATIC AND CONSULAR RELATIONS}

[no entries]

\section{INDIVIDUALS AND GROUPS OF PERSONS - HUMAN RIGHTS}

AKHAVAN, PAYAM, Lessons from Iraqi Kurdistan: Self-determination and Humanitarian Intervention against Genocide, 11 Netherlands Quarterly of Human Rights 41-62 (1993).

AMNESTY InTERNATIONAL, Japan: Inadequate Protection for Refugees and Asylum Seekers, New York, Amnesty International, 1993, 36 pp.

BAR-SiMAN-Tov, YAACOV, Israel and the Peace Process 1977-1982: in Search of Legitimacy for Peace, Albany, State University of New York Press, 1994, 338 pp.

BENVENISTI EYAL, The Influence of International Human Rights Law on the Israeli Legal System, 28 Israel Law Review 136-153 (1994).

BlACK, GEORGE, Genocide in Iraq: the Anfal Campaign against the Kurds, [George Black under the authority of] Human Rights Watch and Middle East Watch, New York, Human Rights Watch, $1993,370 \mathrm{pp}$.

BOUdREAUlt, JODY and YASSER SALAAM (eds.), US Official Statements: the Status of Jerusalem, Washington, DC, Institute for Palestine Studies, 1992, 186 pp.

BRAY, JOHN, Ethnic Minorities and the Future of Burma, 48 The World Today 144-147 (1992).

Chaliand, Gerard, The Kurdish Tragedy, London, Zed, 1994, 120 pp.

A Continuing Cause for Concern: the Military Justice System of the Israeli Occupied Territories, Briefing Paper prepared by The Lawyers Committee for Human Rights, New York, 1993.

Crystal, JiLL, The Human Rights Movement in the Arab World, 16 Human Rights Quarterly 435-454 (1994).

DONOVAn, Dolores A. (ed.), Rebuilding Cambodia: Human Resources, Human Rights, and Law: Three Essays, Washington, DC, Foreign Policy Institute, 1993, 116 pp.

FALKOWSKI, JAMES E., Indian Law/Race Law: a Five-hundred Year History, New York, Praeger, 1992, $170 \mathrm{pp}$.

GinN, JoHn L., Sugamo Prison, Tokyo: an Account of the Trial and Sentencing of Japanese War Criminals in 1948 by a US Participant, Jefferson, McFarland \& Co., 1992, 297 pp.

GoOdhaRT, William, Countdown to 1997: Report of a Mission to Hong Kong, the International Commission of Jurists, Geneva, ICJ, 1992, 120 pp. 
Gosselink, Robert G., Minority Rights and Ethnic Conflict in Assam, India, 14 Boston College Third World Law Journal 83-116 (1994).

GREEN, RANDALl, Human Rights and Most-favored-nation Tariff Rates for Products from the People's Republic of China, 17 University of Puget Sound Law Review 611-636 (1994)

Gunter, MiChael M., The Changing Kurdish Problem in Turkey, London, Research Institute for the Study of Conflict and Terrorism, 1994, 29 pp.

Hussein, FuAD; Leezenberg, Michiel and MUler, Pieter (eds.), The Reconstruction and Economic Development of Iraqi Kurdistan, [Proceedings of the International Conference on the Reconstruction and Development of Iraqi Kurdistan, Zeist, The Netherlands, September 4-6, 1992], Amsterdam, Netherlands-Kurdistan Society, 1993, 112 pp.

Hyman, Anthony, Power and Politics in Central Asia's New Republics, London, Research Institute for the Study of Conflict and Terrorism, 1994, $29 \mathrm{pp}$.

Israel's Children's Rights Monitor and DCI-Israel Three-Year Report 1988, 1989, 1990, Jerusalem, Defense for Children International, Israel Section, 1991, $101 \mathrm{pp}$.

Kaufman, Edy; Abed, Shukry B. and Rothstein, Robert L., Democracy, Peace and the Israeli-Palestinian Conflict, Boulder, Rienner, 1993, 318 pp.

KILJUNEN, Kimmo (ed.), Kampuchea, Decade of the Genocide: Report of a Finnish Inquiry Commission, London, Zed, 1984, 126 pp.

KIM, HYUNG-CHAN, A Legal History of Asian-Americans 1790-1990, Westport, Greenwood Press, 1994, $200 \mathrm{pp}$.

KolinSKY, MarTin, Law, Order and Riots in Mandatory Palestine 1928-35, New York, St. Martin's Press, 1993, 295 pp.

KOLODNER, ERIC, Religious Rights in China: a Comparison of International Human Rights Law and Chinese Domestic Legislation, 16 Human Rights Quarterly 455-490 (1994).

LANDAU, JACOB M., The Arab Minority in Israel 1967-1991: Political Aspects, Oxford, Clarendon Pr., 1993, 237 pp.

LEACH, ANN MOSELEY, Transition to Palestinian Self-government: Practical Steps toward IsraeliPalestinian Peace, Report of a Study Group of the Middle East Program Committee on International Security Studies, Cambridge, American Academy of Arts and Science, 1992, 160 pp.

Leeuwen, Marianne Van, Americans and the Palestinian Question: the US Public Debate on Palestinian Nationhood 1973-1988, Amsterdam, Rodopi, 1993, 545 pp.

LUTZ, ELLEN L., The Marcos Human Rights Litigation: Can Justice be Achieved in US Courts for Abuses that Occurred Abroad?, 14 Boston College Third World Law Journal

MASAlHA, NuR, Expulsion of the Palestinians: the Concept of "Transfer" in Zionist Political Thought 1882-1948, Washington, Institute for Palestine Studies, 1992, 235 pp.

Mor, AWAD MOHAMmed AWAD EL, Human Rights in the Constitutional Systems of Islamic Countries, 18 Revue Al Alqanun Wal Iqtisad 1-75 (1988).

O'DONNELl, DANIEL, Resettlement or Repatriation: Screened-out Vietnamese Child Asylum Seekers and the Convention on the Rights of the Child, 6 International Journal of Refugee Law 382-401 (1994). 
PERRY, Michael S., Worker and Trade Union Rights of Palestinian Arabs from the Occupied Territories, 23 Israel Yearbook of Human Rights 27-52 (1993).

RAGLAND, Thomas K., Burma's Rohingyas in Crisis: Protection of "Humanitarian" Refugees under International Law, 14 Boston College Third World Law Journal 301-336 (1994).

RAMLOGAN, RAJENDRA, The Human Rights Revolution in Japan: a Story of New Wine in Old Wine Skins?, 8 Emory International Law Review 127-213 (1994).

Report on the United Nations Seminar on Assistance to the Palestinian People: papers and statements, [headquarters of the United Nations Educational, Scientific and Cultural Organization, Paris, 26-29 April 1993], New York, United Nations, 1993, 155 pp. (Doc. A/AC 183/MISC 19931).

RöLING, B.V.A (ed.), The Tokyo Trial and Beyond: Reflections of a Peacemonger, Cambridge, Polity Press, 1993, 143 pp.

RUMPF, CHRISTIAN, The Protection of Human Rights in Turkey and the Significance of International Human Rights Instruments, 14 Human Rights Law Journal 394-408 (1993).

SAINI, R.S., Custodial Torture in Law and Practice with Reference to India, 36 Journal of the Indian Law Institute 166-192 (1994).

Schennink, Ben; Merkel, Christine M. and Pavlova-Sylvanskaya, Marina (eds.), Central Asian Civil Society in Search of Partners, [Proceedings of a Conference on Democratisation, Economic Transformation and International Cooperation, Utrecht], Pax Christi Netherlands, 1993, 214 pp.

SHACKLE, ChristoPHER, The Sikhs, London, Minority Rights Group, 1984, 14 pp.

SHIH, CHIH-YU, Contending Theories of "Human Rights with Chinese Characteristics", 29 Issues and Studies (Taipei) 42-64 (1993).

TOMASEVSKI, KATARINA, Human Rights in Eastern Europe, Human Rights in Developing Countries Yearbook, Deventer, Kluwer Law and Taxation, 67-110 (1994).

TOMaSEVSKI, Katarina, Development Aid and Human Rights Revisited, London, Pinter, 1993, $223 \mathrm{pp}$.

UNITED NATIONS (DIVISION FOR PALESTINE RIGHTS), Approaches towards the Settlement of the Arab-Israeli Conflict and the Question of Palestine, Issue 25, June-December 1993, New York, United Nations, 1994, 134 pp.

United Nations Relief and Works Agency for Palestine Refugees in the Near East, UNWRA 19501990: Serving Palestine Refugees, Vienna, UNWRA, 1990, 32 pp.

WaART, PAUl J.I.M. DE, Dynamics of Self-determination in Palestine: Protection of Peoples as a Human Right, Leiden, Brill, 1994, 271 pp.

WEINER, JUSTUS REID, Human Rights in the Israeli Administered Areas during the Intifada, 19871990, 10 Wisconsin International Law Journal 185-281 (1992).

The West Bank and Gaza: Israel's Options for Peace, Report of a JCSS Study Group, Tel Aviv, Tel Aviv University, 1989, 235 pp.

WING, ADRIEN KATHERINE, Custom, Religion and Rights: the Future Legal Status of Palestinian Women, 35 Harvard International Law Journal 149-200 (1994). 
Young, JaQueline M., Torture and Inhuman Punishment of United States' citizens in Saudi Arabia and the United States Government's Failure to Act, 16 HICLR 663-687 (1993).

\section{DECOLONIZATION AND SELF-DETERMINATION}

AKHAVAN, PAYAM, Lessons from Iraqi Kurdistan: Self-determination and Humanitarian Intervention against Genocide, 11 Netherlands Quarterly of Human Rights 41-52 (1993).

CASSESE, ANTONIO, The Israel-PLO Agreement and Self-determination, 4 EJIL 564-571 (1993).

COTTRELL, ROBERT, The End of Hong Kong: the Secret Diplomacy of Imperial Retreat, London, John Murray, 1993, 244 pp.

ESCARAmela, Paula V., Formation of Concepts in International Law: Subsumption under Selfdetermination in the Case of East Timor, Lisbon, Fundacao Oriente, 1933, 244 pp.

JenSEN, SHAwn B., International Agreements between the United States and Hong Kong under the United States-Hong Kong Policy Act, 7 Temple International Comparative Law Journal 167-190 (1993).

KIRBY, MiChaEL, Decision of the Permanent Tribunal of Peoples in its Session on Tibet, Strasbourg, November 1992, 68 The Austrian Law Journal 135-142 (1994).

PARTSCH, KARL, JOSEF, New Findings on the Right of Self-determination for Tibet, 36 German Yearbook of International Law 524-529 (1994).

SAID, EDWARD W., The Politics of Dispossession: the Struggle for Palestinian Self-determination 1969-1994, London, Chatto \& Windus, 1994, 450 pp.

SEGAL, GeRALD, The Fate of Hong Kong, London, Simon \& Schuster, 1993, 234 pp.

SiMPSON, GERRY J., Judging the East Timor Dispute: Self-Determination at the International Court of Justice, 17 HICLR 323-347 (1994).

\section{INTERNATIONAL ECONOMIC RELATIONS}

Clarke, Donald C., GATT Membership for China?, 17 University of Puget Sound Law Review 517-531 (1994).

DAVIDSON, PAUL J., ASEAN: the Legal Framework for its Trade Relations, 49 International Journal 588-612 (1994).

FURNISS, PETER G., The United States-Vietnam Trade Relationship: Politics and Law in the Process of Normalization, 35 Harvard International Law Journal 238-249 (1994).

Hartland-Thunberg, Penelope, China, Hong Kong, Taiwan and the World Trading System, N.Y. St. Martin's Press, 1990. 201 pp.

LALl, K.B., ChOPRA, H.S. and MEYer, ThOMAS (eds.), European Community and SAARC, London, Sangam, 1993, 112 pp.

MASCOLA, ROBERT, Unfair Trade in Steel from Korea? The International Trade Commission's Treatment of Cross-border Dedicated Supplier Relationships, 35 Harvard International Law Journal 201-212 (1994). 
Miller, SuZanNa C., A Double Standard: the United States' Plea for per se Illegality of the Japanese Keiretsu, 19 Brooklyn Journal of International Law 1101-1137 (1993).

STEPHENSON, SHERry M., ASEAN and the Multilateral Trading System, 25 Law and Policy in International Business 439-448 (1994).

TAYLOR, JAMES JR., Vietnam: The Current Legal Environment for US Investors, 25 Law and Policy in International Business 469-479 (1994).

WANG, GUIGUO, China's return to GATT, 28 Journal of World Trade 51-65 (1994).

WUNKER, ROBERT L., The Laws of Vietnam Affecting Foreign Investment, 28 The International Lawyer 363-383 (1994).

Yoon, Yomin, The Korean Chip Dumping Controversy: Are They Accused of Violating an Unjust Law?, 19 North Carolina Journal of International Law and Commercial Regulation 247-266 (1994).

\section{DEVELOPMENT}

NaKagawa, JUnJ, Legal Problems of Japan's ODA Guidelines: Aid and Democracy, Human Rights and Peace, 36 JAIL 76-99 (1993).

WILliams, MARC, International Economic Organisations and the Third World, New York, Harvester Wheatsheaf, 1994, 229 pp.

\section{INFORMATION AND COMMUNICATION}

Floum, Joshua R., Counterfeiting in the People's Republic of China: The Perspective of the "Foreign" Intellectual Property Holder, 28 Journal of World Trade 35-59 (1994).

ViswanANTHAN, APARNA, Special 301: Analysis of Intellectual Property Disputes between India and USA, 37 Journal of the Indian Law Institute 127-154 (1993).

\section{UNITED NATIONS AND OTHER INTERNATIONAL/REGIONAL ORGANIZATIONS}

Amjad Ali S., Prospects of Cooperation with Central Asian States, 46 Pakistan Horizon 55-70 (1993).

Cooperation in the Asia-Pacific Region: Perspectives from the United States, Russia and Japan, 48 Austrian Journal of International Affairs 61-95 (1994).

HAAS, DEBORAH A., Out of Other's Shadows: ASEAN Moves Toward Greater Regional Cooperation in the Face of the EC and NAFTA, 9 The American Univiversity Journal of International Law and Policy 809-867 (1994).

HiCKey, DenNis VAN VRANKen, Coming in from the Cold: Taiwan's Return to International Organizations, 30 Issues and Studies 94-107 (1994).

HIROBE, KAZUYA, Article 98 Paragraph 2 of the Constitution of Japan and the Domestic Effects of Resolutions of the United Nations Security Council, 36 JAIL 17-32 (1993). 
Kawari, Hamad Abdelaziz AL, The Decision-making Process of the UN Security Council: the Iran-Iraq War as a Case Study, Annals of Arbitration, UMI, 1990, 350 pp.

LUHULIMA, C.P.F., Indonesia's Initiative in APEC, 22 IQ 304-319 (1994).

LuHulima, C.P.F., The Performance of ASEAN Economic Cooperation, 22 IQ 15-21 (1994).

Parasher, S.C. (ed.), United Nations and India, New Delhi, Indian Council of World Affairs, $1985,415 \mathrm{pp}$.

SOESASTRO, HADI, APEC and the Asia Pacific: an ASEAN Perspective, 22 IQ 341-354 (1994).

WANG, VINCENT WeI-CHENG, How can Taiwan Enter the United Nations? History, Issues and Approaches, 30 Issues and Studies 108-131 (1994).

WoOdS, LAWRENCE T., Asia-Pacific Diplomacy: Nongovernmental Organizations and International Relations, 7 Canada and International Relations, Vancouver, UBC Press, 1993, 257 pp. 